\title{
WPŁYW ZMIANY PEŁNIONYCH FUNKCJI NA FIZJONOMIĘ PORTU W USTCE
}

\author{
The impact of changes in the performed functions on the physiognomy of the port in Ustka
}

\section{Tomasz Michalski}

Zakład Rozwoju Regionalnego, Instytut Geografii Społeczno-Ekonomicznej i Gospodarki Przestrzennej, Uniwersytet Gdański, J. Bażyńskiego 4, 80-309 Gdańsk e-mail: tomasz.michalski@ug.edu.pl

iD https://orcid.org/0000-0002-7916-9620

\section{Cytacja:}

Michalski T., 2021, Wpływ zmiany pełnionych funkcji na fizjonomię portu w Ustce, Prace Komisji Geografii Komunikacji PTG, 24(3), 64-75.

\begin{abstract}
Streszczenie: Celem artykułu jest przedstawienie wpływu zmiany funkcji pełnionych przez port w Ustce na jego fizjonomię. Analiza funkcjonalna dotyczy głównie okresu 2016-2019. Natomiast analizę fizjonomii przeprowadzono dla 2021 r. Stwierdzono, że podstawowa dla portów funkcja przeładunkowa jest w Ustce pełniona w minimalnym stopniu. Funkcja turystyki morskiej jest realizowana w stopniu niewystarczającym (brak mariny jachtowej), a żeglugi pasażerskiej nie jest realizowana. Port pełni nadal funkcję rybołówstwa i wędkarstwa rekreacyjnego, ale w stopniu mniejszym, niż w przeszłości. Działalność produkcyjna na terenie portu nie jest już prowadzona, chociaż w przeszłości była realizowana na dużą skalę. Istnieje szansa, że w porcie rozwinie się funkcja związana z konserwacją i eksploatacją farm wiatrowych. Obecnie w porcie rozwijają się silnie funkcja turystyczna (gastronomia, hotele itd.) oraz mieszkaniowa. Wprowadzenie tej ostatniej funkcji do portu uznano za błąd. Zmiany funkcji powodują zmiany w fizjonomii portu. Znikają obiekty przemysłowe i przeładunkowe, a na ich miejsce pojawiają się obiekty z funkcją hotelową i gastronomiczną oraz mieszkaniowe, aczkolwiek zmiany te zachodzą z dużym opóźnieniem.
\end{abstract}

Słowa kluczowe: funkcje portowe, port w Ustce, małe porty morskie

Abstract: The aim of the article is to present the impact of changes in the functions performed by the port in Ustka on its physiognomy. The functional analysis mainly covers the period of 2016-2019, while the analysis of the physiognomy was conducted for 2021. It was found that the basic trans-shipment function is played to a minimum extent in Ustka. The function of sea tourism is insufficiently realized (no yacht marina), and the function of passenger shipping is not performed. The function of recreational fishing and angling is still performed by the port, but to a lesser extent than in the past. There is no longer any production activity in the port area, although in the past it was carried out on a large scale. There is a chance that the port will develop a function related to the maintenance and operation of wind farms. On the other hand, the tourist function (gastronomy, hotels, etc.) and housing are strongly developing in the port. Introducing the latter function into the port was considered a mistake. Changes in functions result in changes to the port physiognomy. Industrial and trans-shipment facilities are disappearing and replaced with hotel, catering and residential facilities. However, these changes are long delayed.

Keywords: port functions, port in Ustka, small sea ports 


\section{Wstęp}

Upadek komunizmu w Polsce wyzwolił procesy transformacji ustrojowej, które doprowadziły do znaczących przeobrażeń we wszystkich sferach życia społecznego, w tym politycznego i gospodarczego (por. Bałtowski, Miszewski, 2006; Chojnicki i in., 1999; Kołodko, 2009; Wallas, 2010). Objęły one także polskie porty, powodując daleko idące zmiany w ich funkcjonowaniu, jak i zagospodarowaniu przestrzennym. Na podstawie literatury przedmiotu, dotyczącej zarówno dużych portów' (Grzybowski, 2017; Palmowski, Wendt, 2021; Pluciński, 2013; Tarkowski, 2015), jak i małych (Karwacka, Bursztyński, 2011; Luks, 2011; Michalski, 2020; Szymańska, Michalski, 2018) można pokusić się o stwierdzenie, że duże porty, tj. Gdańsk, Gdynia, Świnoujście i częściowo Szczecin² radzą sobie w nowej rzeczywistości o wiele lepiej, niż porty małe. Zapewne skutkuje to szybszymi zmianami w fizjonomii i zagospodarowaniu przestrzennym dużych portów, niż małych - ale odrzucenie lub przyjęcie tej hipotezy wymaga osobnych badań.

Zasadniczym rodzajem działalności portów morskich jest funkcja przeładunkowa (Rozkrut, Rozkrut, 2015). Tym niemniej do podstawowych form aktywności w portach można zakwalifikować także (Luks, 2011):

1. Rozwój morskich klastrów sportowo-turystycznych oraz żeglugi pasażerskiej;

2. Rozwój rybołówstwa i wędkarstwa rekreacyjnego;

3. Przeładunki towarów i obsługę statków handlowych (wspomnianą już wcześniej);

4. Działalność produkcyjną prowadzoną na terenie portu i w jego otoczeniu;

5. Obsługę działalności poszukiwawczej i wydobywczej w polskiej strefie ekonomicznej;

6. Obsługę konserwacji i eksploatacji farm wiatrowych. W dalszej części opracowania poddano analizie spełnianie przez port w Ustce tych sześciu podstawowych funkcji, by następnie zaprezentować pozostałe funkcje pełnione przez port przedstawiając jednocześnie ich skutki dla jego fizjonomii. Stąd celem niniejszego opracowania jest przedstawienie wpływu zmiany funkcji pełnionych przez port w Ustce na jego fizjonomię.

Za Luksem (2011) zaliczono do nich Gdańsk, Gdynię, Szczecin oraz Świnoujście.

2 W świetle obecnych tendencji rozbudowy portów istotnym ograniczeniem dla rozwoju portu szczecińskiego są uwarunkowania środowiskowe związane $z$ jego położeniem w głębi lądu (68 km od morza oraz dostępny dla statków o zanurzeniu do 9,15 m (Cywiński, 2019) i koniecznością pogłębiania toru wodnego (Sułek, Tołkacz, 2011; Wiśnicki, Klabacha, Borowiec, 2007). Osobną kwestię stanowi efektywność działalności gospodarczej podmiotów zlokalizowanych na terenie portu.
Analiza funkcjonalna dotyczy głównie okresu 20162019. Ponieważ wpływ zmian pełnionych funkcji znajduje odzwierciedlenie w fizjonomii nieraz z kilkuletnim nawet opóźnieniem, dlatego analizę fizjonomii portu usteckiego przeprowadzono dla $2021 \mathrm{r}$.

Zasięg przestrzenny opracowania obejmuje położony u ujścia Słupi do Bałtyku port w Ustce w jego granicach administracyjnych, aczkolwiek odwoływano się także do procesów zachodzących w granicach administracyjnych gminy miejskiej Ustka. Dodatkowo dokonano porównań usteckiego portu z innymi małymi polskimi portami morskimi.

\section{1. Źródła danych i metody analizy}

Źródła danych, którymi posłużono się w pracy można podzielić na trzy grupy. Pierwszą stanowią dane udostępniane przez Główny Urząd Statystyczny wespół z Urzędem Statystycznym w Szczecinie. W tym przypadku skorzystano z roczników statystycznych gospodarki morskiej (Rocznik..., 2000; 2004; 2007; 2020).

Druga grupa źródeł to witryny internetowe oraz dokumenty i opracowania. Wykorzystano tutaj metody niereaktywne, w szczególności analizę danych wtórnych (Borowska-Beszta i in., 2017; Heaton, 2008).

Trzecie źródło stanowiły przeprowadzone w lutym i maju 2021 r. badania terenowe na obszarze usteckiego portu oraz w jego najbliższym sąsiedztwie. Ich efektem są m.in. zdjęcia, które posłużyły do ilustracji niektórych ze formułowanych w artykule wniosków.

\section{Funkcje usteckiego portu}

Jak wspomniano, za najważniejszą funkcję portów uważa się funkcję przeładunkową. Nabrzeża przeładunkowe w Ustce mają zaledwie 160 m długości, a do portu mogą wchodzić jednostki o maksymalnej długości $80 \mathrm{~m}$ i zanurzeniu $4 \mathrm{~m}^{3}$. Place składowe zajmują łącznie 3 tys. $\mathrm{m}^{2}$. Niestety w porcie nie ma już czynnych linii kolejowych, najbliższa bocznica znajduje się w odległości 500 m (Port Handlowy, b.d.). W omawianym czasie port w Ustce pełnił funkcję przeładunkową w minimalnym stopniu. W okresie 2016-2019 jedynie w ostatnim roku odnotowano nieznacznie większe przeładunki - 37,3 tys. ton, podczas gdy we wcześniejszych trzech latach przeładowywano średnio 0,5 tys. ton rocznie. Były to ładunki masowe suche (niezjednostkowane) ze Szwecji. O upadku funkcji przeładunkowej portu usteckiego świadczy fakt, że np. w okresie 1996-2000 średnia przeładunków wynosiła jeszcze 33,4 tys. Na zanik tej funkcji względem innych małych polskich portów wskazuje ryc. 1, na

\footnotetext{
W wyjątkowych sytuacjach, po spełnieniu dodatkowych
} warunków zanurzenie statku może osiągnąć do 4,3 m. 


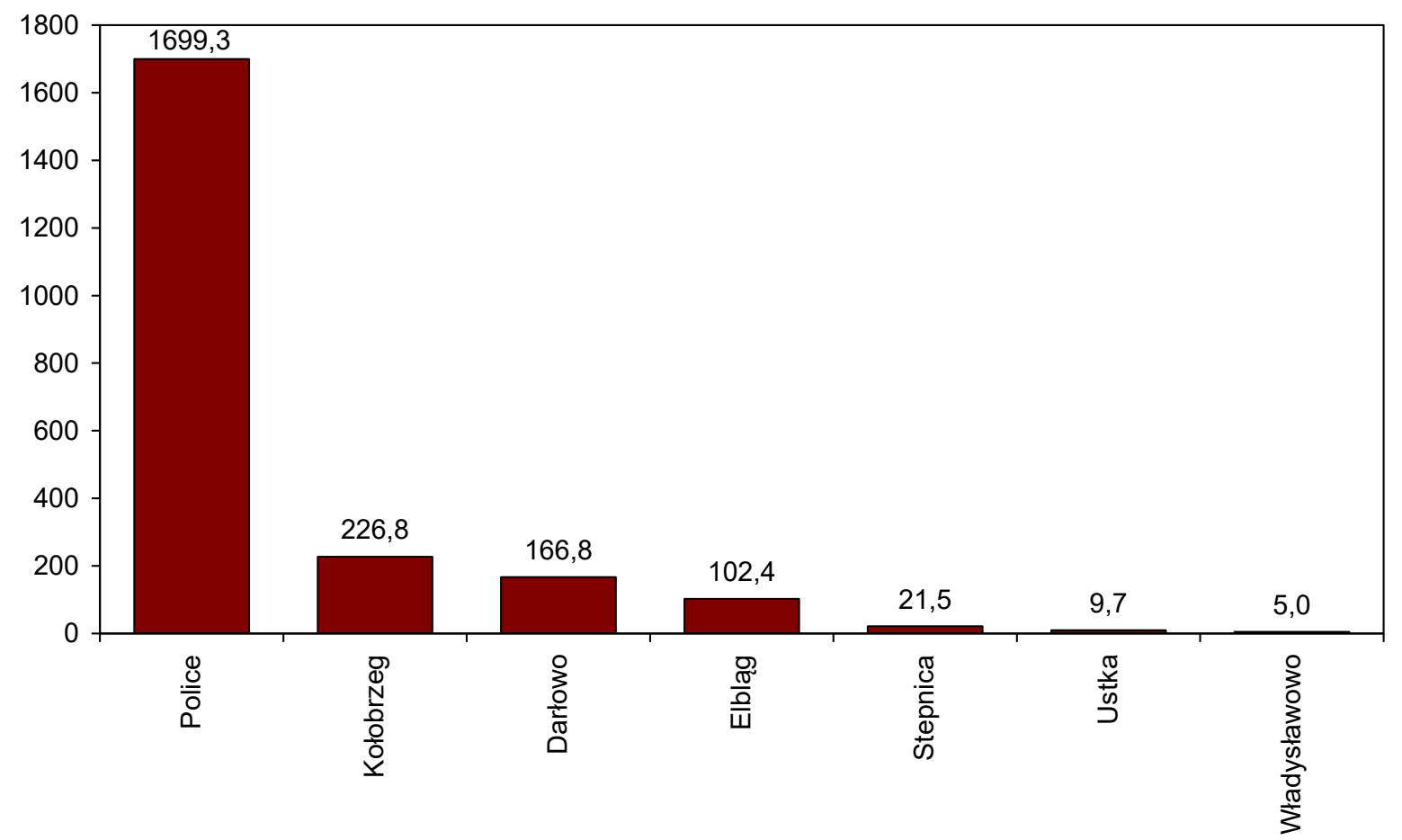

Ryc. 1. Średnioroczne obroty ładunkowe [w tys. ton] w małych portach Polski, średnia z lat 2016-2019.

Źródło: Opracowanie własne na podstawie Rocznik Statystyczny Gospodarki Morskiej 2020, tab. 4.9, s. 108-123.

której pokazano średnioroczne przeładunki w latach 2016-2019. Wynika z niej, że mniejsze przeładunki odnotowano jedynie w porcie we Władysławowie.

Szansą dla pełnienia tej funkcji mogła być planowana rozbudowa portu ${ }^{4}$. Niestety, w 2020 r. zrezygnowano nawet z przebudowy wejścia do portu (Rzeczkowska, 2020). Także zmodernizowana linia kolejowa UstkaSłupsk omija tereny portowe. Nieudaną próbą ożywienia funkcji przeładunkowej portu było powołanie wolnego obszaru celnego, który istniał jedynie w latach 1989-1993 (Rozporządzenie..., 1989; Obwieszczenie..., 1993; Rozporządzenie..., 1993), aczkolwiek cały czas pojawiają się inicjatywy podtrzymania tej funkcji. Na przykład, według jednej z nich ustecki port miałby być wykorzystany do przeładunków przez wojska amerykańskie w związku z ich częstymi pobytami na usteckim poligonie oraz w bazie w Redzikowie (Nałęcz, 2021).

Prawie całkowity zanik funkcji przeładunkowej znajduje odzwierciedlenie w zagospodarowaniu portu. Za ilustrację jej upadku może posłużyć stan techniczny dużego spichlerza (ryc. 2), do którego nie prowadzi już nawet czynna linia kolejowa.

Funkcja morskich klastrów sportowo-turystycznych oraz żeglugi pasażerskiej w usteckim porcie jest pełniona w mocno zróżnicowany sposób. O ile funkcje sportowo-turystyczne można uznać za częściowo

4 Swoim rozmachem przypominała ona niezrealizowane niemieckie plany z 1937 r. (por. Szopowski, 1962). realizowane, o tyle funkcja żeglugi pasażerskiej prawie nie istnieje. Spośród funkcji turystycznych portu na pierwsze miejsce wysuwa się pełnienie przez niego roli przystani jachtowej ${ }^{5}$. Rola ta nie jest jednak w pełni realizowana, gdyż brakuje w porcie mariny, jak ma to miejsce chociażby w porcie kołobrzeskim. Jednostki sportowe i rekreacyjne mogą cumować przy 460 m nabrzeży portowych ${ }^{6}$ (Marina Jachtowa, b.d.). Zatem częstokroć jachty cumują w porcie razem z kutrami rybackimi (ryc. 3). Brakuje także w pełni rozwiniętej infrastruktury lądowej niezbędnej do obsługi załóg jachtów i rezydentów. Sytuacja w tym zakresie uległa niewielkiej poprawie od 2010 r., dla którego Nowaczyk (2016) analizując infrastrukturę żeglarską

Należy tutaj wprowadzić rozróżnienie między terminami przystań jachtowa i marina jachtowa. Jak podaje NowaCzyk (2016, s. 108), ta pierwsza to "wyodrębniony obszar portów morskich przygotowany od strony technicznej do obsługi ruchu żeglarskiego. Charakteryzuje się ograniczoną ilością miejsc postojowych oraz skromniejszym wyposażeniem w infrastrukturę towarzyszącą". Marina jest natomiast „przygotowana od strony technicznej do obsługi ruchu żeglarskiego, z większą ilością miejsc postojowych oraz z reguły wyposażona w infrastrukturę towarzyszącą". Tak więc w Ustce mamy do czynienia z przystanią, a nie z mariną jachtową.

6 Nabrzeża: Słupskie, Kołobrzeskie, Władysławowskie, Sopockie, ale np. pobór wody pitnej jest możliwy tylko przy nabrzeżach Kołobrzeskim i Sopockim (na 190 m długości), a odbiór nieczystości płynnych tylko przy Kołobrzeskim (100 m). 


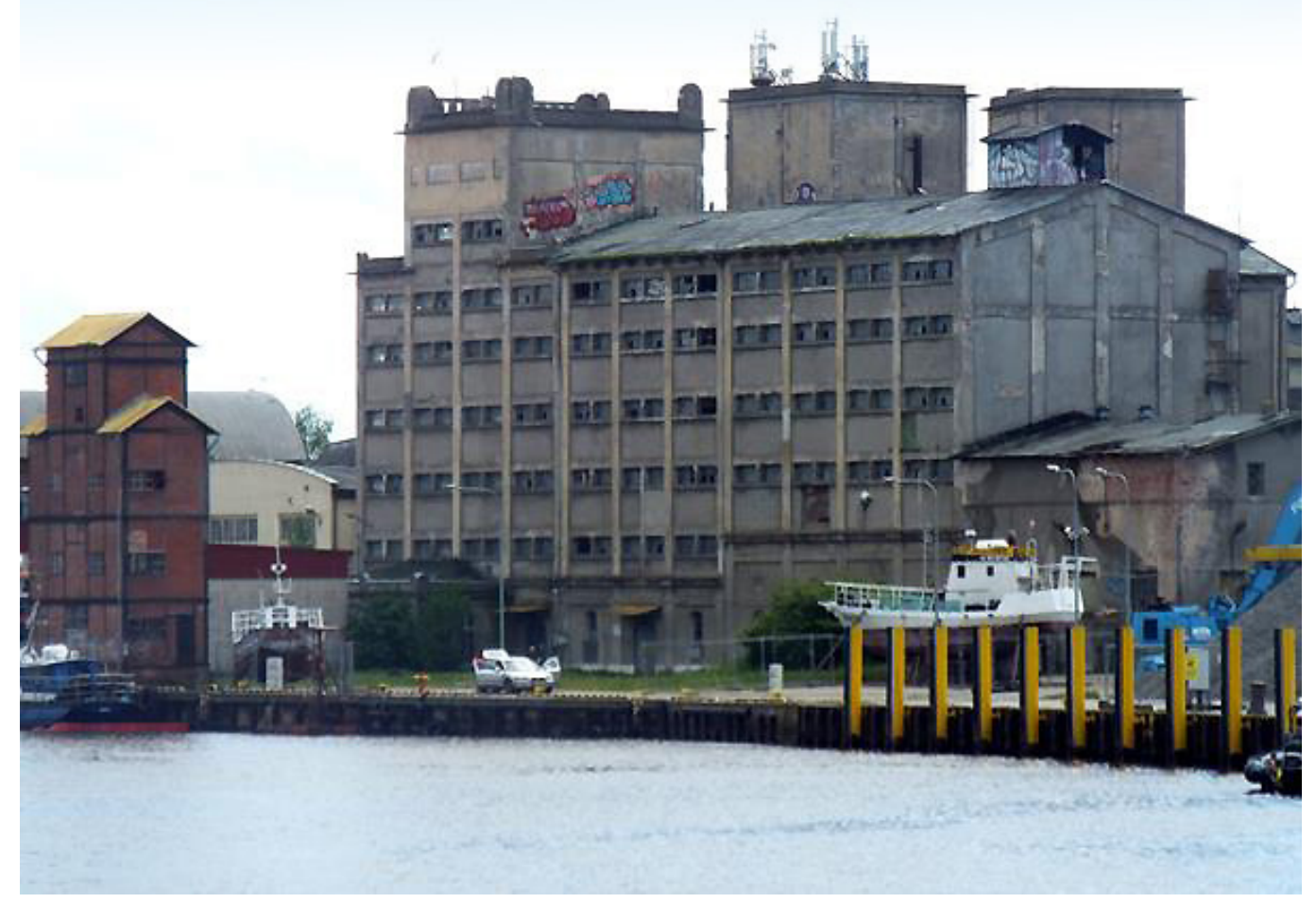

Ryc. 2. Żurawik i spichlerz w usteckim porcie, stan w 2021 r.

Źródło: T. Michalski.

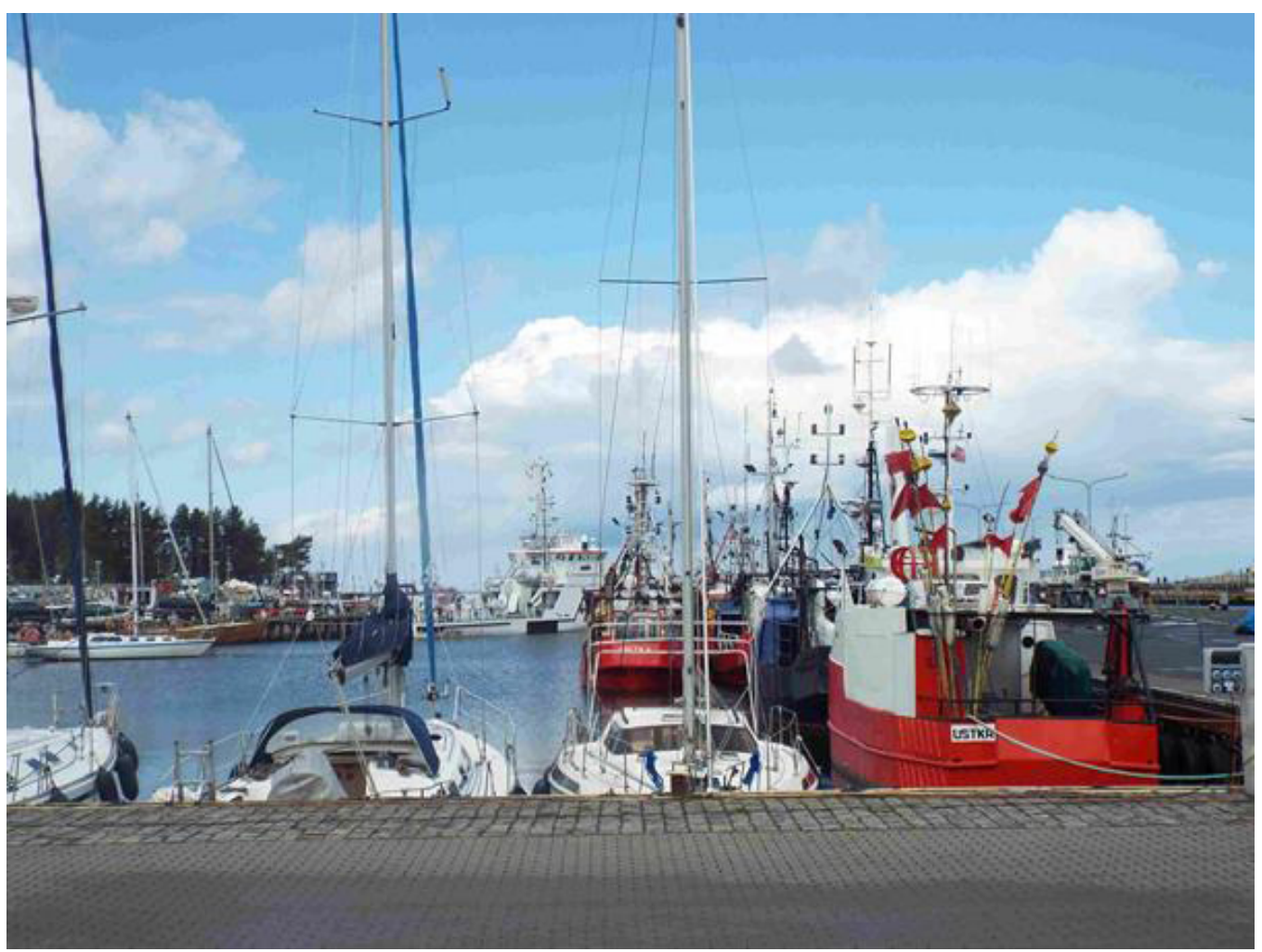

Ryc. 3. Jachty i kutry w basenie portowym w Ustce, stan w 2021 r.

Źródło: T. Michalski. 
małych portów morskich stwierdził, że w Ustce brakuje infrastruktury żeglarskiej zarówno podstawowej, jak i uzupełniającej. Wprawdzie przez cały czas istnieją plany budowy mariny w basenie w głębi lądu (Projekt..., 2014) lub między falochronami (Szansa..., b.d.), ale jak na razie nie widać ich wymiernych efektów. Ruch jachtów w porcie jest relatywnie niewielki, np.w 2017 r. odwiedziło go ponad 500 jednostek (Szansa..., b.d.).

Na uwadze należy mieć ponadto, że funkcja turystyczna jest realizowana głównie w sezonie letnim, tak więc jej wpływ prorozwojowy pozostaje ograniczony. W 2019 r. na 392,9 tys. udzielonych noclegów w turystycznych obiektach noclegowych na terenie miasta Ustka aż 84,7\% przypadło na okres czerwiec-sierpień. Oczywiście Ustka pełni również rolę uzdrowiska (W. Szymańska, 2012), które jest czynne przez cały rok, ale akurat port dla pełnienia tej funkcji ma znaczenie marginalne.

Natomiast funkcja pasażerska w okresie 20162019 nie była realizowana w usteckim porcie. Liczba pasażerów statków pasażerskich w porcie w Ustce wyniosła 0 . W tym przypadku port ustecki cechuje sytuacja typowa dla portów leżących nad otwartym morzem o mało urozmaiconej linii brzegowej. Pomijając Kołobrzeg - w pozostałych portach (Darłowo, Łeba, Władysławowo) nie odnotowano także obsługi żadnych pasażerów statków pasażerskich. Ruch ten był notowany głównie w portach usytuowanych na wybrzeżach o urozmaiconej linii brzegowej (ryc. 4), aczkolwiek i w tej grupie są wyjątki, np. Nowe Warpno czy Puck i Elbląg, gdzie także nie odnotowano ruchu pasażerskiego.

Z Ustki, podobnie jak z innych małych portów, nie prowadzi żadna linia promowa oraz nie zawijają do niej wycieczkowce. W pasażerskim ruchu międzynarodowym w Ustce w omawianym okresie odnotowano tylko jednego pasażera. Pod tym względem zróżnicowanie przestrzenne małych portów było częściowo podobne jak wcześniej. To znaczy, że ruchu tego nie odnotowały małe porty na Wybrzeżu Środkowym, ale dodatkowo usytuowane także nad Zatoką Gdańską i Zalewem Wiślanym. Ruch ten wystąpił na Wybrzeżu Zachodnim (ryc. 5).

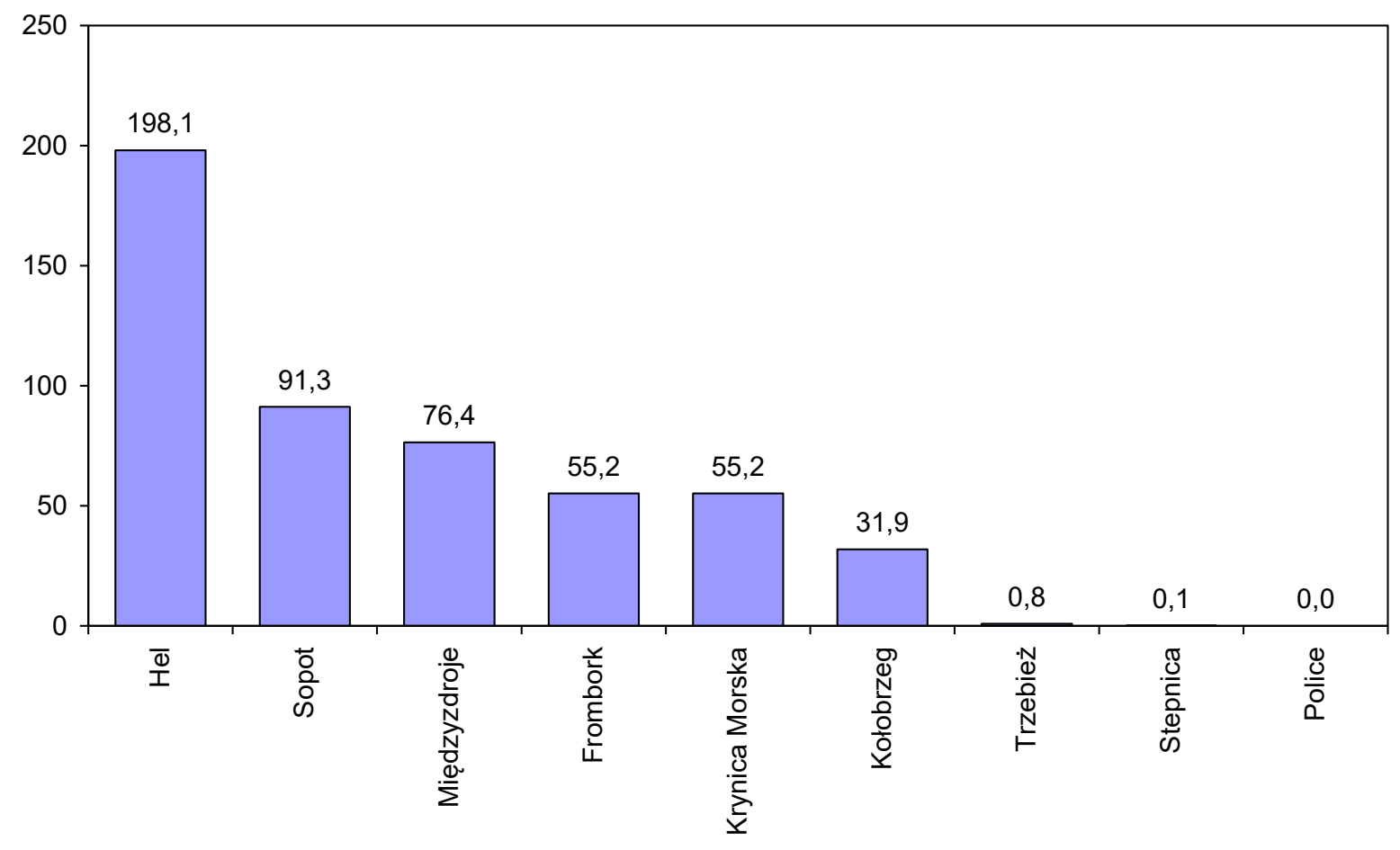

Ryc. 4. Średnioroczna liczba pasażerów [w tys.] statków pasażerskich zawijających do małych portów Polski, średnia z lat 2016-2019.

Źródło: Opracowanie własne na podstawie Rocznik Statystyczny Gospodarki Morskiej 2020, tab. 4.9, s. 108-123. 
Nie oznacza to, że z Ustki nie kursują statki wycieczkowe. Znajdziemy tu jedynie łodzie lub statki stylizowane na galeony (ryc. 6), oferujące krótkie rejsy po morzu. Szansę ożywienia ruchu pasażerskiego stanowią sezonowe rejsy na Bornholm. Są one realizowane $z$ Kołobrzegu, natomiast w przypadku Ustki i Darłowa mamy do czynienia z naprzemiennymi sezonami wznawiania i zawieszania tych połączeń. finansowania złomowania jednostek rybackich (por. Kutry..., 2019; Złomowanie..., b.d.).

O ile w przypadku poprzednio omawianych funkcji port ustecki przedstawiał się skromnie na tle innych małych polskich portów - o tyle w przypadku funkcji rybackiej należy do ich czołówki. Razem z Kołobrzegiem sytuuje się na drugim miejscu po Władysławowie (ryc. 7). Pojemność brutto (GT) tej floty wynosi w Ustce 1,6 tys., a jej moc to 4,6 tys. $k W^{9}$. To że spada wielkość

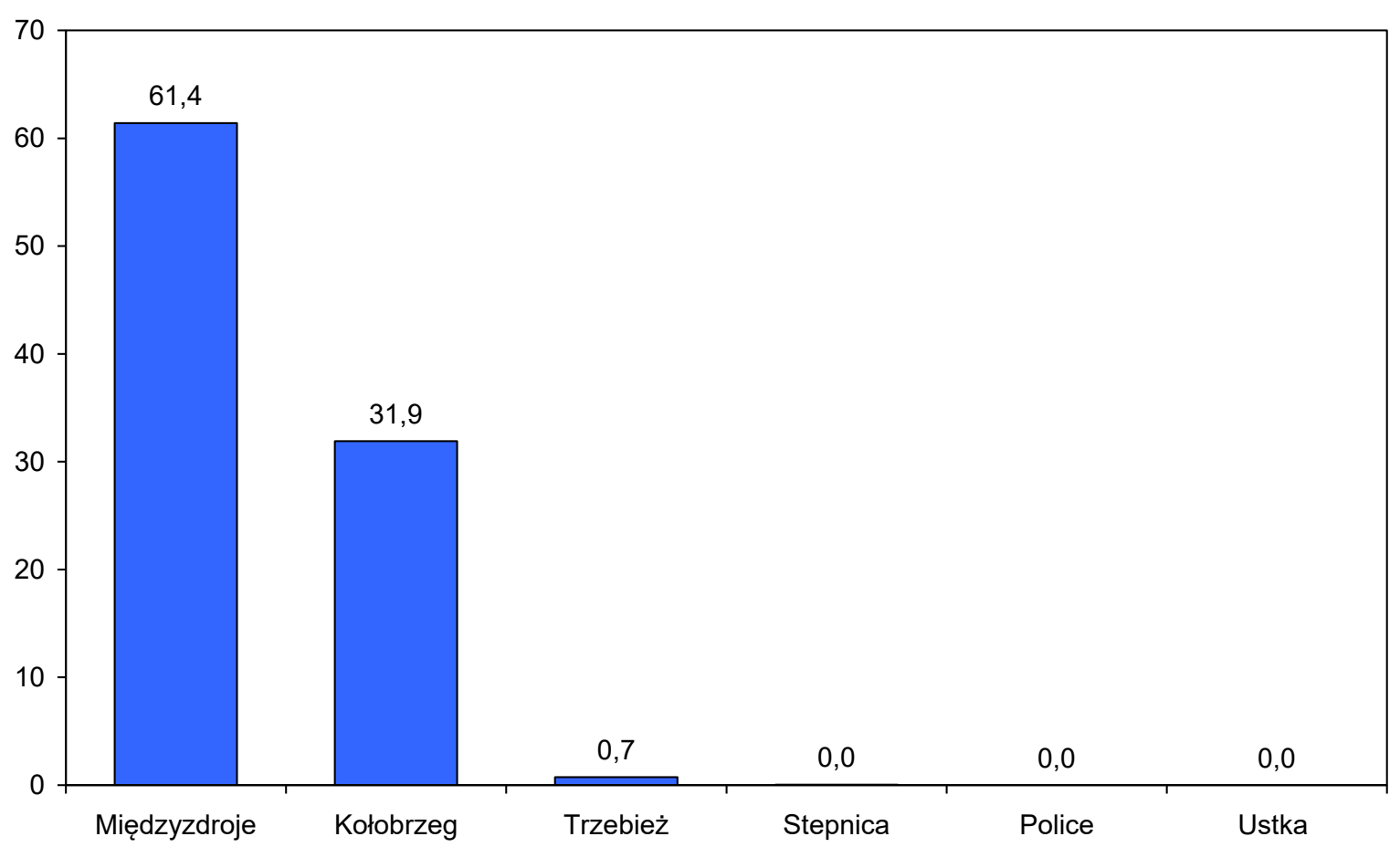

Ryc. 5. Średnioroczna liczba pasażerów [w tys.] w międzynarodowym ruchu pasażerskim w małych portach Polski, średnia $z$ lat 2016-2019.

Źródło: Opracowanie własne na podstawie Rocznik Statystyczny Gospodarki Morskiej 2020, tab. 4.13, s. 154-155.

Polskie rybołówstwo już od początku procesu transformacji zmaga się z licznymi utrudnieniami i problemami (Kłosiński, 1994). Skutkuje to spadkiem wielkości połowów ryb i bezkręgowców morskich. Jeszcze w 1990 r. wynosiły one 430 tys. ton, by w 2019 r. spaść do 195 tys. ton. Pociąga to za sobą spadek liczby jednostek dokonujących połowów. Wpływ na ich liczebność ${ }^{7}$, oprócz różnorakich uwarunkowań ekonomicznych, ma także postępująca degradacja Bałtyku i spadek liczebności ławic ryb (por. Aps, Lassen, 2010; Lindegren i in., 2009). Powiązana z tym jest polityka Unii Europejskiej, skutkująca z jednej strony przyznawaniem bardzo małych kwot połowowych na Bałtyku', a z drugiej prowadzeniem polityki do-

7 Pominięto analizę czynników wpływających na wielkość dalekomorskiej floty łowczej.

8 Na przykład TAC 2021 dla Polski wyniósł 467,2 ton na dorsza 22-24 oraz 157,3 na dorsza 25-32 (Karnicki, 2020). floty połowowej oraz wielkość samych połowów nie oznacza, że nie powinny być w tej materii podejmowane działania prorozwojowe. W przypadku Ustki takim działaniem jest powstanie już w 2004 r. lokalnego centrum pierwszej sprzedaży ryb (ryc. 8), które jednak od momentu powstania boryka się z problemami (por. Czapliński, 2012; Hryszko i in., 2008).

Dotychczas wsparciem dla rybaków było morskie wędkarstwo rekreacyjne. Niestety, ze względu na zły stan stada dorsza atlantyckiego we wschodniej części Morza Bałtyckiego od 2020 r. zakazano połowów rekreacyjnych tej ryby m.in. w podregionie ICES 25 (Rozporządzenie..., 2019), na brzegu którego jest położony ustecki port. Tak więc ta forma zarobkowania

\footnotetext{
9 Aczkolwiek należy mieć na uwadze, że nastąpiło znaczne zmniejszenie tej floty, gdyż w momencie wstępowania Polski do UE pojemność brutto (GT) usteckich kutrów wynosiła 3,9 tys.
} 


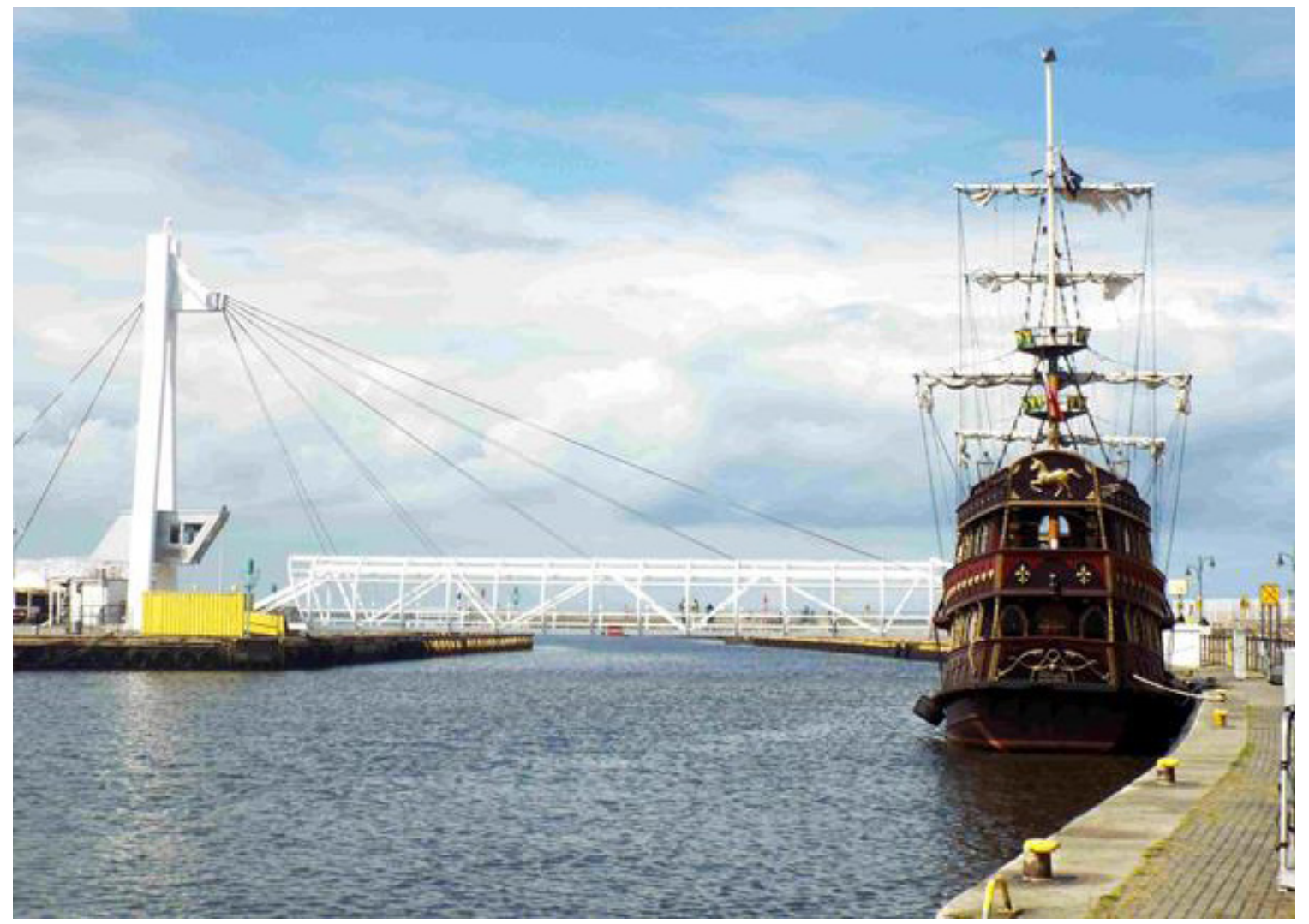

Ryc. 6. Statek wycieczkowy stylizowany na galeon oraz przesuwana kładka w porcie usteckim, stan w 2021 r. Źródło: T. Michalski.

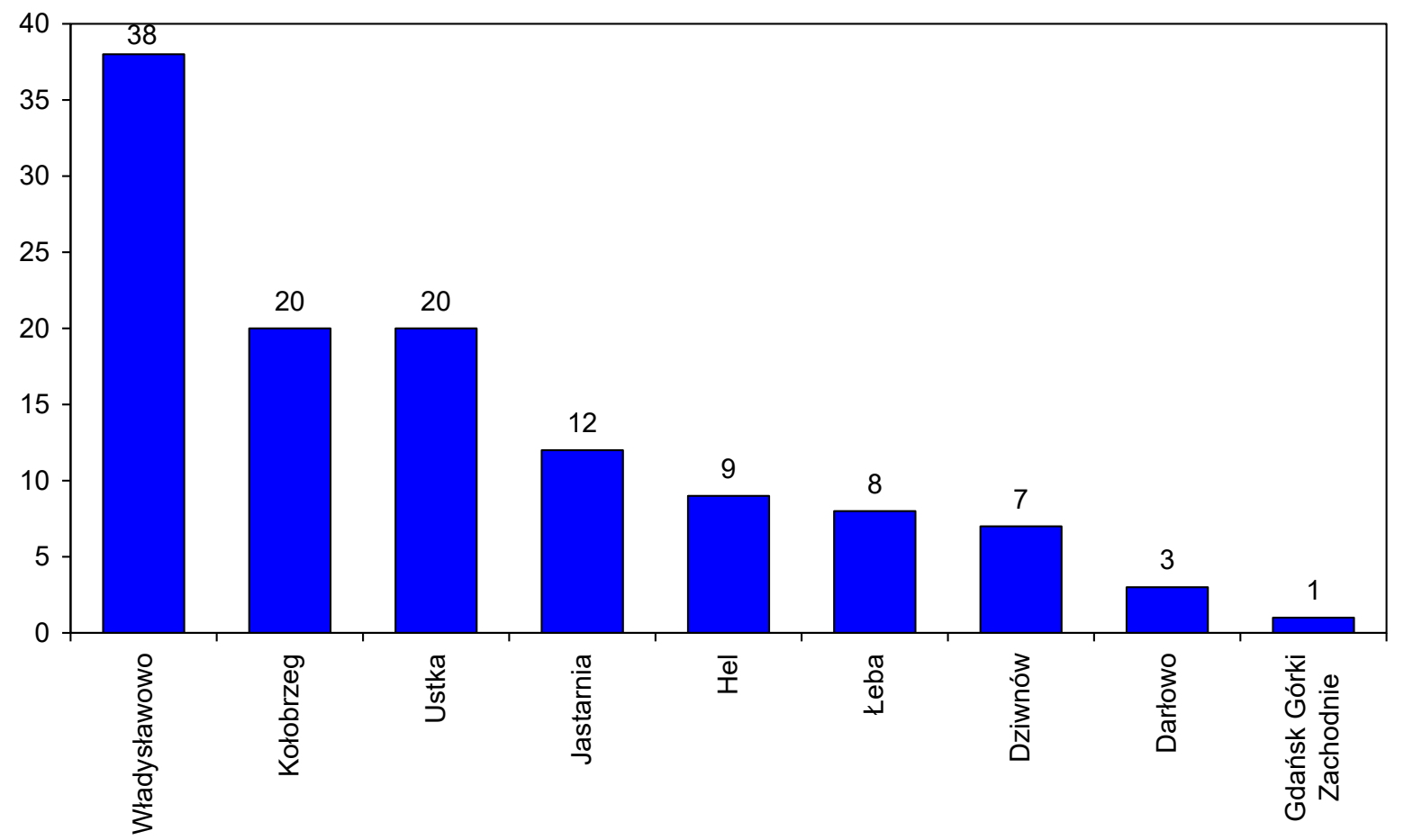

Ryc. 7. Liczba kutrów [w sztukach] w małych portach Polski, stan na 31 XII 2019 r.

Źródło: Opracowanie własne na podstawie Rocznik Statystyczny Gospodarki Morskiej 2020, tab. 8.3, s. 211. 


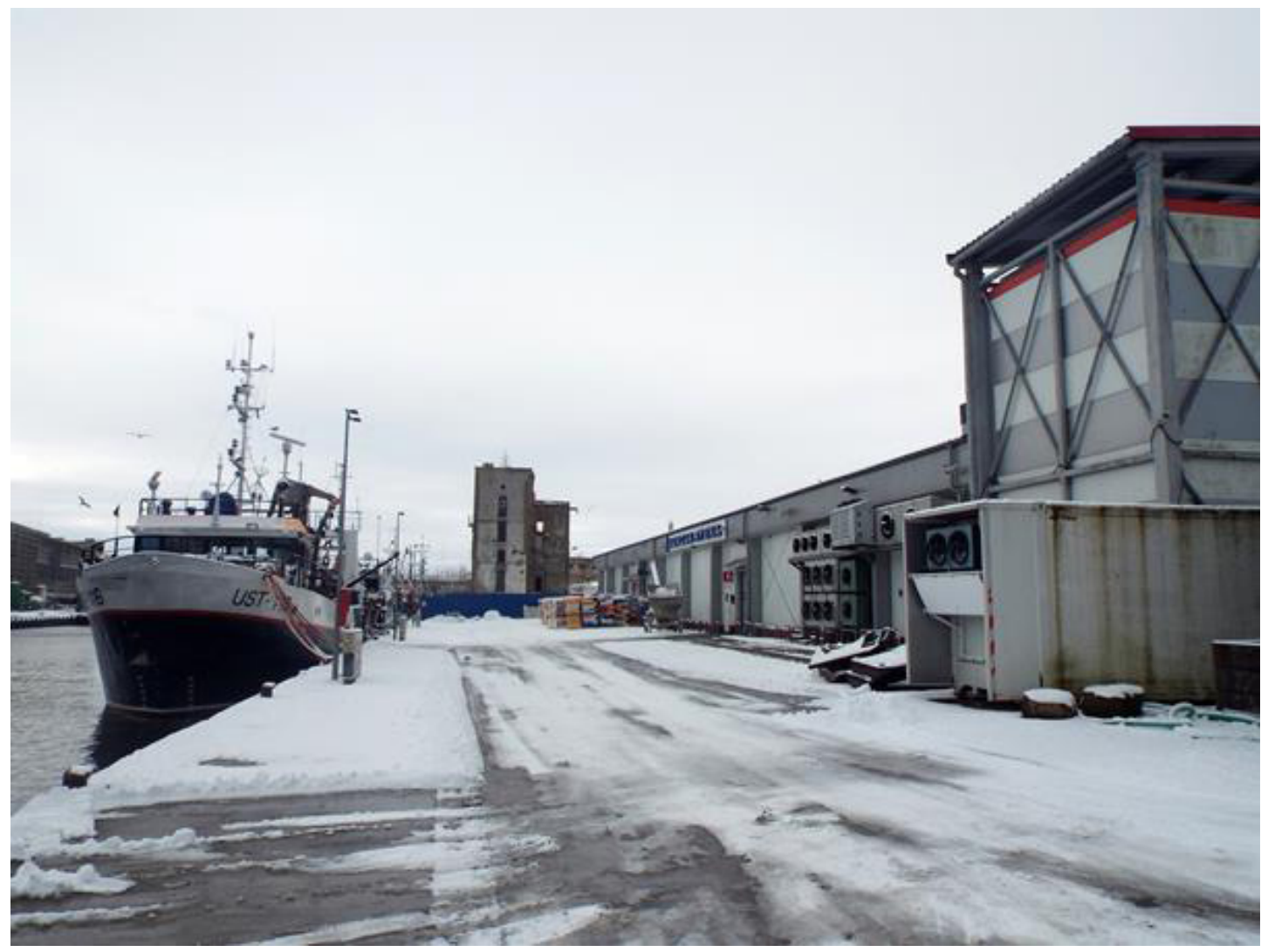

Ryc. 8. Lokalne centrum pierwszej sprzedaży ryb w Ustce, 2021 r.

Źródło: T. Michalski.

straciła wiele ze swej atrakcyjności dla potencjalnych wędkarzy.

W przeszłości na terenie usteckiego portu z powodzeniem prowadzona była działalność przemysłowa. Obejmowała po pierwsze przetwórstwo ryb, co swego czasu stanowiło typowy przemysł zlokalizowany w małych portach. Aktualnie na terenie usteckiego portu nie ma żadnej większej firmy zajmującej się przetwórstwem ryb. Zresztą, jak zauważa Czapliński $(2013,2018)$, działalność ta wcale nie musi być obecnie lokowana w portach, czy szerzej - w strefie nadmorskiej i aktualnie jest w zaniku na terenach portowych. Najlepiej pokazuje to historia firmy Przetwórstwo Rybne "Łosoś", która powstała w 1954 r. w Ustce i do 1999 r. funkcjonowała jako spółdzielnia pracy. Obecnie jako Przetwórstwo Rybne "Łosoś" Sp. z o.o. jest zlokalizowana w Słupskiej Specjalnej Strefie Ekonomicznej - we Włynkówku k. Słupska. Także drugie usteckie przedsiębiorstwo związane z rybołówstwem i przetwórstwem ryb, tj. „Korab" S.A. Przedsiębiorstwo Połowów Przetwórstwa i Handlu - już nie istnieje.

Unikatowość gospodarczą usteckiego portu wśród innych małych polskich portów zapewniało istnienie od 1945 r. stoczni. Najprężniej działała ona w latach
80. XX w. produkując zestawy ratunkowe dla statków ${ }^{10}$, konstrukcje stalowe na statki oraz statki stalowe do 30 m długości częściowo wyposażone, kutry rybackie, wyroby z laminatów - jachty, łodzie motorowe, poduszkowce oraz inne wyposażenie ze stali i aluminium. Już w drugiej połowie lat 90. XX w. stocznia zaczęła jednak przeżywać trudności. W efekcie tego w 2002r. ogłoszono jej upadłość (Pacuk, Michalski, 2002). O ile na terenach postoczniowych zlokalizowanych w porcie pozostała jeszcze zabudowa przemysłowa (chociaż obszar ten został okrojony w związku z miejskimi inwestycjami), to na terenie postoczniowym położonym tuż poza portem nie pozostało już prawie nic z zabudowy (ryc. 9).

Spośród dwóch ostatnich wymienionych przez Luksa (2011) podstawowych form aktywności portów, tj. obsługi działalności poszukiwawczej i wydobywczej w polskiej strefie ekonomicznej oraz obsługi konserwacji i eksploatacji farm wiatrowych - w porcie usteckim żadna $\mathrm{z}$ tych działalności nie jest realizowana. Port w Ustce może stać się jednak bazą

10 Stocznia w Ustce była wyłącznym producentem pływającego sprzętu ratunkowego w Polsce. 


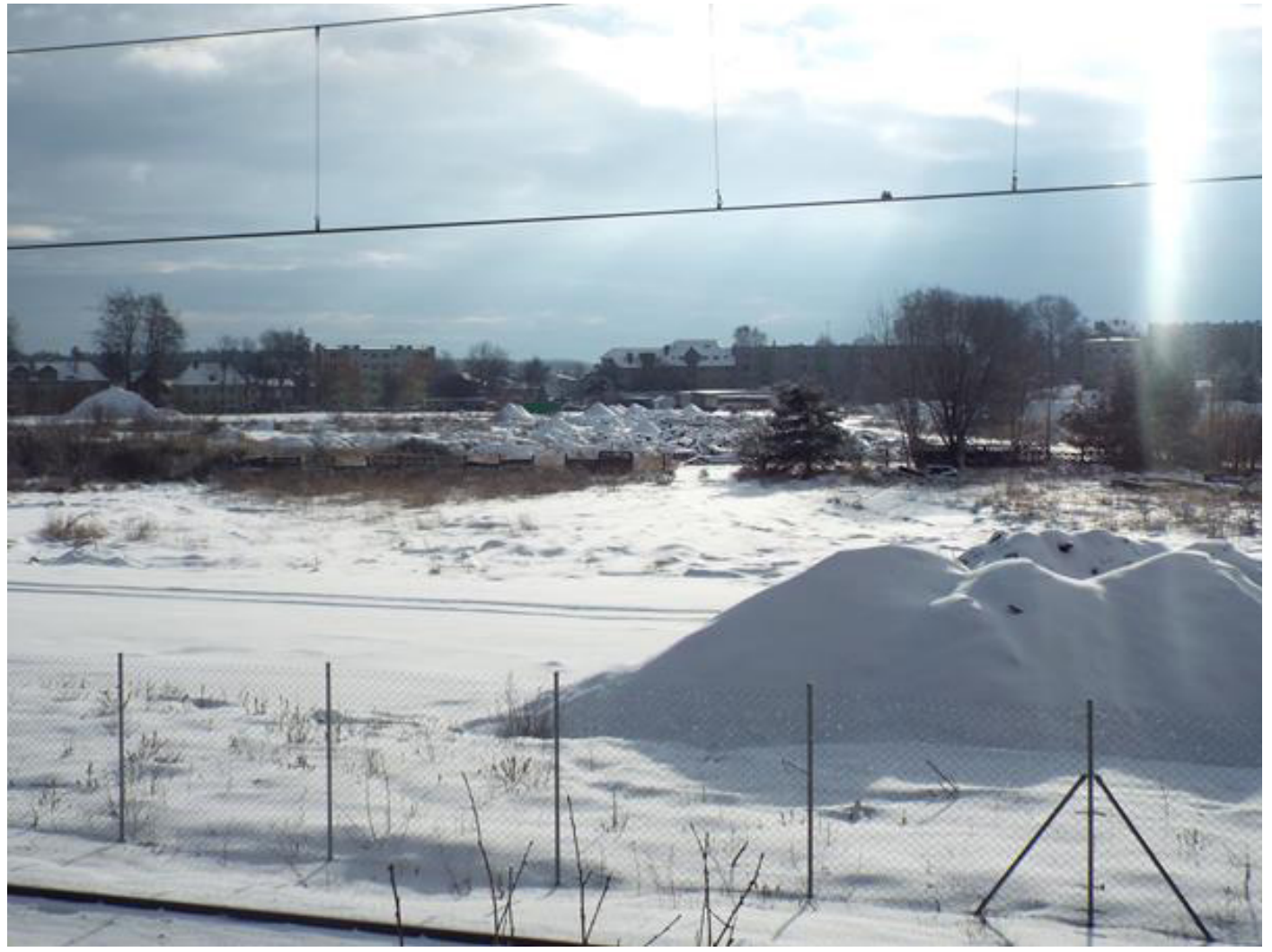

Ryc. 9. Pozostałości zabudowy na terenach stoczniowych w Ustce, 2021 r.

Źródło: T. Michalski.

serwisową dla planowanych morskich farm wiatrowych. W 2021 r. list intencyjny w tej sprawie podpisali przedstawiciele PGE, PGE Baltica i Urzędu Miasta Ustka (Port..., 2021).

Ponadto port ustecki stanowi siedzibę morskiej stacji ratowniczej (należącej do Morskiej Służby Poszukiwania i Ratownictwa), która składa się z brzegowej stacji ratowniczej oraz morskiego statku ratowniczego (typu SAR-3000). Jest to jedna z 14 placówek tej służby na polskim wybrzeżu (Morska..., b.d.). W przeszłości w Ustce często stacjonowały także okręty Marynarki Wojennej, co było związane $z$ istnieniem w Lędowie k. Ustki jednostki wojskowej.

W związku z przemianami zachodzącymi w małych portach - w porcie usteckim pojawiły się lub nabrały znaczenia dwie nowe funkcje. Pierwsza to funkcja turystyczna. Oczywiście port pełnił tę funkcję od zawsze, ale wobec spadku znaczenia innych (opisanych powyżej) jego funkcji, przy jednoczesnym wzroście roli funkcji turystycznej w rozwoju miasta Ustka - funkcja turystyczna portu wzrosła. Bezpośrednią przyczyną jej rozwoju było uwolnienie sporej części terenów portowych spod działalności przeładunkowej, rybackiej bądź przemysłowej. Zresztą ten proces trwa cały czas.

Należy jednakże wyraźnie zaznaczyć, że port ustecki pełni raczej funkcję uzupełniającą w realizacji funkcji turystycznej na terenie miasta Ustka. Główną atrakcją kurortu są szerokie piaszczyste plaże. Oferta dla turystów zlokalizowana w porcie ${ }^{11}$ - tereny udostępnione do spacerowania (zwłaszcza nabrzeża portowe i falochrony), baza dla łodzi i statków świadczących usługi wędkarstwa morskiego oraz krótkich rejsów po morzu (ryc. 6), obiekty gastronomiczne, hotele (ryc. 10), udostępniona do zwiedzania latarnia morska oraz ruchoma kładka (ryc. 6) - stanowi uzupełnienie dla plaż.

Niestety, od niedawna port pełni także funkcję mieszkaniową. W jego centralnej części, po wschodniej stronie zostały zlokalizowane budynki mieszkalne (ryc. 10). Część z tych mieszkań służy do wynajmu krótkoterminowego (co znajduje potwierdzenie chociażby w wyszukiwarce booking.com), a część jest wykorzystywana do okazjonalnego wypoczynku lub stanowi zapewne lokatę kapitału.

\section{Wnioski}

Mające miejsce po 1990 r. procesy transformacji ustrojowej w Polsce znacząco wpłynęły na pełnione przez ustecki port funkcje. Zmiany te uległy przyspieszeniu po przystąpieniu Polski do Unii Europejskiej. Oczywiście istnieje także całe spektrum innych czynników

11 Częściowo wspominano już o niej przy okazji omawiania innych funkcji portu. 


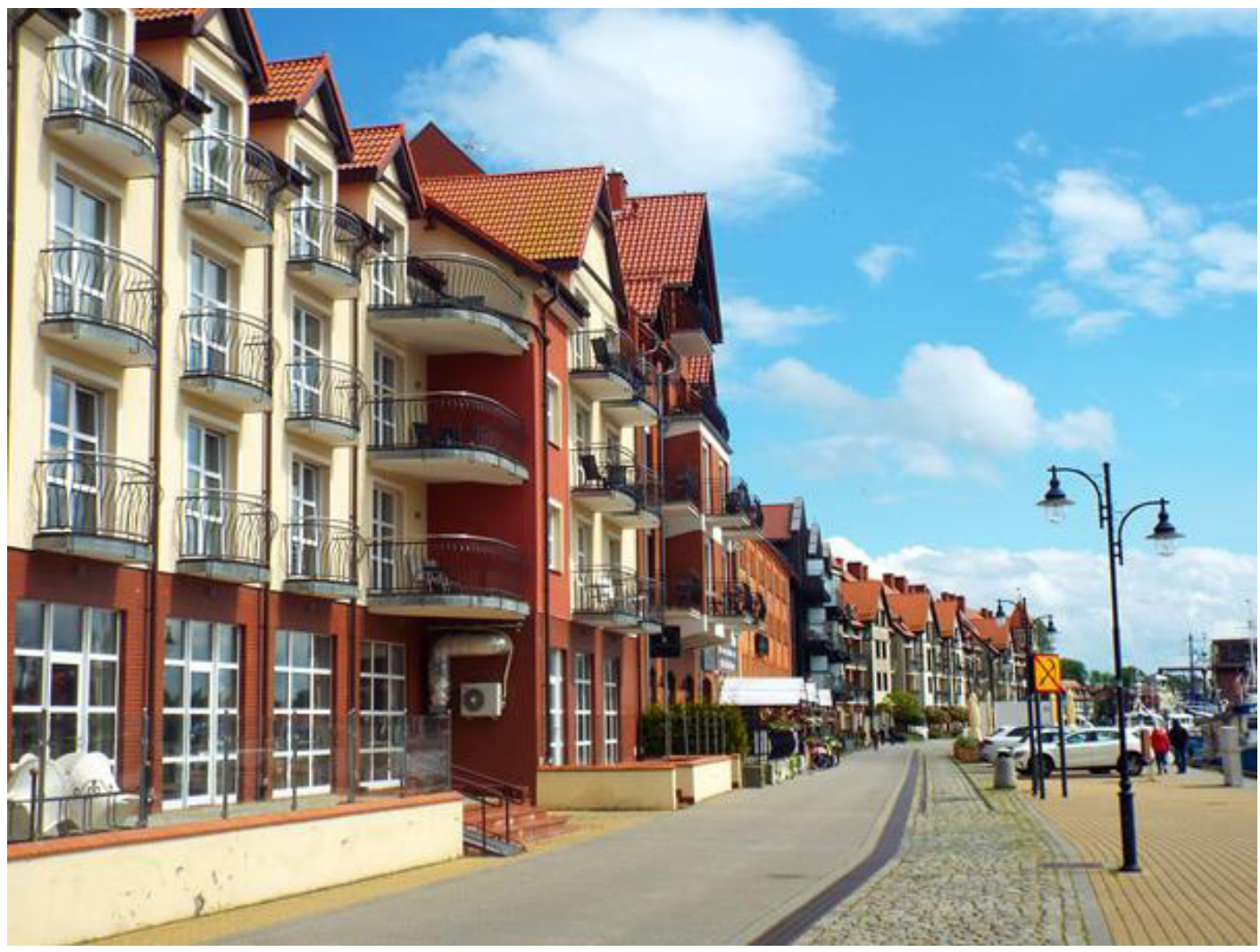

Ryc. 10. Zabudowa turystyczna (na pierwszym planie) i mieszkaniowa (w głębi) na nabrzeżach Słupskim i Lęborskim w porcie w Ustce, 2021 r.

Źródło: T. Michalski.

wpływających na zmiany funkcji usteckiego portu, jak np. przełowienie Bałtyku czy przemiany w transporcie morskim.

Prawie całkowity zanik funkcji przeładunkowej, częściowy zanik funkcji bazy dla jednostek łowiących ryby oraz całkowity zanik funkcji przemysłowej - spowodowały uwolnienie dużych obszarów w porcie. Część tych obszarów aktualnie nie jest użytkowana lub użytkowana ekstensywnie. Ze względu na ich pogarszający się stan techniczny wpływają one negatywnie na percepcję usteckiego portu. Są to głównie obszary zlokalizowane w głębi portu, po obu stronach Słupi. Natomiast część z tych obszarów, zwłaszcza po wschodniej stronie portu, zmieniła całkowicie swój wygląd - zrewitalizowano stare lub powstały nowe budynki pełniące funkcje turystyczne lub mieszkaniowe. Dzięki temu ta część portu wygląda estetycznie (ryc. 10), ale należy sobie postawić pytanie: czy wprowadzenie funkcji mieszkaniowej to usteckiego portu było słuszne? Z kolei przemiany $w$ handlu rybami skutkowały powstaniem nowego budynku aukcji rybnej po zachodniej stronie portu. Plany utworzenia w Ustce bazy dla remontów i konserwacji farm wiatrowych powinny w najbliższym czasie przyczynić się do rozwoju nowej zabudowy po zachodniej stronie portu.
Brak większych inwestycji infrastrukturalnych w usteckim porcie od zakończenia II wojny światowej' ${ }^{12}$ można traktować jako jego wadę i zaletę zarazem. Wadę - dlatego, że zbyt małe rozmiary portu utrudniają pełnienie przez niego funkcji przeładunkowych, natomiast zaletę - gdyż port ten częściowo zachował jeszcze klimat z początku XX w., co podnosi jego atrakcyjność turystyczną ${ }^{13}$. Zbyt małe rozmiary portu są jednak także poważnym ograniczeniem dla powstania w nim mariny jachtowej.

12 Chociaż tuż po objęciu tych terenów przez Polskę snuto plany rozbudowy małych portów (Bublewski (red.), 1947; Potrzeby..., 1949). Zresztą w przypadku usteckiego portu do tematu wrócono po wstąpieniu Polski do UE i pisano już nawet o konkretnych planach i środkach finansowych na ich realizację (Pałys, 2015; Szykuje..., 2015).

13 Obecnie zachodzą już jednak duże zmiany. Na przykład, w związku z planowaną lokalizacją bazy turbin wiatrowych w Ustce zachodzi konieczność likwidacji zabytkowego żurawika (ryc. 2). Na szczęście istnieją plany przeniesienia go do innej części portu (Rzeczkowska, 2021). 


\section{Piśmiennictwo:}

Aps R., Lassen H., 2010, Recovery of depleted Baltic Sea fish stocks: a review, ICES Journal of Marine Science, 67, 1856-1860.

Bałtowski M., Miszewski M., 2006, Transformacja gospodarcza w Polsce, Wydawnictwo Naukowe PWN, Warszawa.

Borowska-Beszta B., Bartkowska U., Ćwirynkało K., 2017, Analiza wtórna jakościowych danych zastanych: przegląd założeń teoretycznych i aplikacji metodologicznych, Jakościowe Badania Pedagogiczne, 2(1), 5-24.

Bublewski W. (red.), 1947, Pierwszy Zjazd Związu Gospodarczego Miast Morskich, Związek Gospodarczy Miast Morskich, Gdańsk.

Chojnicki Z., Czyż T., Parysek J., 1999, Transformation and dilemmas of the Polish economy [w:] W.F. Carter, W. Maik (red.), Shock - shift in an enlarged Europe, Ashgate, Aldershot, 7-26.

Cywiński M., 2019, Perspektywy rozwoju transportu morskiego w Polsce, Zeszyty Naukowe ZPSB FIRMA i RYNEK, 1(55), 79-88.

Czapliński P., 2012, Lokalne centrum pierwszej sprzedaży ryb jako narzędzie regulacji rynku rybnego na przykładzie LCPSR - Aukcji Rybnej Ustka Sp. z o.o., Słupskie Prace Geograficzne, 9, 5-22.

Czapliński P., 2013, Przestrzenny wymiar funkcjonowania i rozwoju przemysłu przetwórstwa rybnego w Polsce, Wydawnictwo Bernardinum, Pelplin.

Czapliński P., 2018, Przemiany w polskim przemyśle przetwórstwa rybnego, Prace Komisji Geografii Przemysłu Polskiego Towarzystwa Geograficznego, 32(2), 60-72.

Grzybowski M., 2017, Inwestycje modernizacyjne i rozwojowe w polskich portach. Studia przypadków, Finanse, Rynki Finansowe, Ubezpieczenia, 1/2017, 609-619.

Heaton J., 2008, Secondary Analysis of Qualitative Data: An Overview, Historical Social Research, 33(3), 33-45.

Hryszko K., Kuzebski E., Mickiewicz M., Pieńkowska B., Rembeza J., Seremak-Bulge J., Szostak S., Wołos A., 2008, Rozwój rynku ryb i zmiany jego funkcjonowania w latach 1990-2007, Instytut Ekonomiki Rolnictwa i Gospodarki Żywnościowej - Państwowy Instytut Badawczy, Warszawa.

Karnicki Z., 2020, A w Luksemburgu bez zmian, Wiadomości Rybackie, 9-10(237), 3.

Karwacka K., Bursztyński A., 2011, Porty środkowego wybrzeża. Charakterystyka i potencjalne zagrożenia dla infrastruktury portowej, Logistyka, 5/2011, 685-696.

Kłosiński W., 1994, Morska gospodarka rybna w Polsce, Wiadomości Rybackie, 1(38), 1-3.

Kołodko G.W., 2009, A two-thirds rate of success: Polish transformation and economic development 1989-2008, Communist and Post-Communist Studies, 42(3), 325-351.

Lindegren M., Möllmann C., Nielsen A., Stenseth N. C., 2009, Preventing the collapse of the Baltic cod stock through an ecosystem-based management approach, Proceedings of the National Academy of Sciences of the United States of America, 106(34), 14722-14727.

Luks K., 2011, Strategia aktywizacji nadbałtyckich regionów peryferyjnych wobec zjawiska marginalizacji małych portów w Polsce, Problemy Transportu i Logistyki, 15, 193-273.

Michalski T., 2020, Czy mamy do czynienia z regresem małych polskich portów i przystani morskich?, Prace Komisji Geografii Komunikacji PTG, 23(5), 61-72.

Nowaczyk P., 2016, Determinanty rozwoju działalności żeglarskiej małych portów morskich w Polsce, Folia Pomeranae Universitatis Technologiae Stetinensis, Oeconomica, 324(82)1, 107-116.

Obwieszczenie Prezesa Rady Ministrów z dnia 25 sierpnia $1993 \mathrm{r}$. w sprawie ogłoszenia wykazu zniesionych z dniem 30 czerwca 1993 r. wolnych obszarów celnych, 1993, Dz.U. 1993 nr 81 poz. 383.

Pacuk M., Michalski T., 2002, Problemy funkcjonowania małych portów morskich na przykładzie Ustki [w:] J. Wendt (red.), Wybrane zagadnienia geografii transportu, Zakład Geografii Społecznej i Turyzmu i Zakład Geografii Ekonomicznej Morza Uniwersytet Szczeciński, Szczecin, 143-158.

Palmowski T., Wendt J., 2021, Wpływ inwestycji i modernizacji portów morskich w Gdańsku i Gdyni na zmiany struktury przeładunków portowych, Przegląd Geograficzny, 93(2), 269-290.

Pluciński M., 2013, Polskie porty morskie w zmieniającym się otoczeniu zewnętrznym, CeDeWu, Warszawa.

Potrzeby i możliwości rozwoju małych portów polskiego wybrzeża, 1949, Jantar, 3/4, 196-205.

Rocznik Statystyczny Gospodarki Morskiej 2000, 2000, GUS, GUS Szczecin, Warszawa-Szczecin.

Rocznik Statystyczny Gospodarki Morskiej 2004, 2004, GUS, GUS Szczecin, Warszawa-Szczecin.

Rocznik Statystyczny Gospodarki Morskiej 2007, 2007, GUS, US Szczecin, Warszawa-Szczecin.

Rocznik Statystyczny Gospodarki Morskiej 2020, 2020, GUS, US Szczecin, Warszawa-Szczecin.

Rozkurt M., Rozkrut D., 2015, Tendencje rozwojowe w obszarach polskich portów morskich z uwzględnieniem tranzytu, Studia i Prace Wydziału Nauk Ekonomicznych i Zarządzania, 42(1), 241-256.

Rozporządzenie Rady (UE) 2019/1838 z dnia 30 października 2019 r. ustalające uprawnienia do połowów na 2020 rok wodniesieniu do niektórych stad rybigrup stad ryb w Morzu Bałtyckim oraz zmieniające rozporządzenie (UE) 2019/124 wodniesieniu do uprawnień do połowów w innych wodach, 2019, Dziennik Urzędowy Unii Europejskiej, L 281/1.

Rozporządzenie Rady Ministrów z dnia 2 czerwca 1989 r. wsprawie ustanowienia wolnego obszaru celnego w Ustce, 1989, Dz.U. 1989 nr 37 poz. 202.

Rozporzadzenie Rady Ministrów z dnia 31 sierpnia 1993 r. uchylające niektóre rozporządzenia w sprawie ustano- 
wienia wolnych obszarów celnych, 1993, Dz.U. 1993 nr 83 poz. 389.

Sułek J., Tołkacz L., 2011, Środowiskowe aspekty wzrostu dostępności Portu Szczecin drogą morską, Problemy Transportu i Logistyki, 15, 97-107.

Szopowski Z., 1962, Małe porty Pomorza Zachodniego wokresie drugiej wojny światowej, PWN, Warszawa-Poznań.

Szymańska W., 2012, Miasto Ustka jako uzdrowisko - rozwój przestrzenny i funkcjonalny [w:] E. Rydz (red.), Ekonomiczne i organizacyjne aspekty funkcjonowania polskich uzdrowisk, Akademia Pomorska w Słupsku, Słupsk, 209-236.

Szymańska W., Michalski T., 2018, Przekształcenia funkcji małych portów morskich, Prace Komisji Geografii Komunikacji PTG, 21(3), 70-77.

Tarkowski M., 2015, Porty morskie w Gdańsku i Gdyni po 25 latach transformacji gospodarczej, Prace Komisji Geografii Przemysłu Polskiego Towarzystwa Geograficznego, 29(2), 147-161.

Wallas T., 2010, Transformacja systemowa w Polsce i jej konsekwencja. Przyczynek do oceny [w:] T. Wallas (red.), Między historia, politologia a medioznawstwem. Wybór problemów, Wydawnictwo Naukowe WNPiD UAM, Poznań, 361-374.

Wiśnicki B., Klabacha M., Borowiec A., 2007, Analiza wpływu zmiany głębokości toru wodnego Szczecin-Świnoujście na rozwój zespołu portowego Szczecin-Świnoujście [w:] K. Chwestiuk (red.) Funkcjonowanie i rozwój polskich portów morskich wświetle zapisów „Zielonej Księgi” polityki morskiej Unii Europejskiej, Wydawnictwo Kreos, Szczecin, 329-337.

\section{Źródła internetowe:}

Kutry na dorsze do wycofania, 2019, https://ec.europa. eu/poland/news/191031_cod_pl\#top-page [dostęp: 29.10.2020].

Marina Jachtowa, b.d., https://ustkaport.pl/marina-jachtowa/ [dostęp: 24.06.2021].

Morska Służba Poszukiwania i Ratownictwa, b.d., https:// www.sar.gov.pl/pl/location/gdynia/ [dostęp: 25.06.2021].
Nałęcz K., 2021, Wielkie plany i tak samo duże problemy. Czy port w Ustce zostanie przebudowany?, https://m. radiogdansk.pl/slupsk/item/133149-wielkie-plany-i-tak-samo-duze-problemy-czy-port-w-ustce-zostanie-przebudowany/133149-wielkie-plany-i-tak-samo-duze-problemy-czy-port-w-ustce-zostanie-przebudowany [dostęp: 25.06.2021].

Pałys E., 2015, Krok w kierunku rozbudowy portu w Ustce, https://www.rynekinfrastruktury.pl/wiadomosci/krok-w-kierunku-rozbudowy-portu-w-ustce--52202.html [dostęp: 25.06.2021.

Port Handlowy, b.d., https://ustkaport.pl/port-handlowy/ [dostęp: 23.06.2021].

Port w Ustce może być bazq̨ serwisową farm wiatrowych PGE, 2021, https://www.pap.pl/mediaroom/978226\%2Cport-w-ustce-moze-byc-baza-serwisowa-farm-wiatrowych-pge.html [dostęp: 25.06.2021].

Projekt mariny w Ustce zatwierdzony. Miasto otrzyma $38 \mathrm{~m} / \mathrm{n}$ zł, 2014, https://gp24.pl/projekt-mariny-w-ustce-zatwierdzony-miasto-otrzyma-38-mln-zl/ar/4836933 [dostęp: 25.06.2021].

Rzeczkowska B., 2020, Przebudowa wejścia portu w Ustce wstrzymana. Będą nowe projekty, https://ustka.naszemiasto.pl/przebudowa-wejscia-portu-w-ustce-wstrzymana-beda-nowe/ar/c1-7826482 [dostęp: 25.06.2021].

Rzeczkowska B., 2021, Zabytkowyżurawik znika z zachodniej części portu w Ustce. Musi ustapić bazie turbin wiatrowych, https://ustka.naszemiasto.pl/zabytkowy-zurawik-znika-z-zachodniej-czesci-portu-w-ustce/ar/c1-8472023 [dostęp: 25.06.2021].

Szansa na usteckq̨ marinę, b.d., https://ustkaport.pl/szansa-na-ustecka-marine/ [dostęp: 24.06.2021].

Szykuje się gigantyczna przebudowa wejścia do portu morskiego w Ustce, 2015, https://www.portalmorski.pl/ inne/28110-szykuje-sie-gigantyczna-przebudowa-wejscia-do-portu-morskiego-w-ustce [dostęp: 25.06.2021].

Złomowanie statków rybackich, https://www.arimr.gov.pl/ dla-beneficjenta/biblioteka/archiwum/programy-i-dzialania-wdrozone-w-poprzednich-latach/spo-rybolowstwo-i-przetworstwo-ryb-2004-2006/zlomowanie-statkow-rybackich.html [dostęp: 29.10.2020]. 